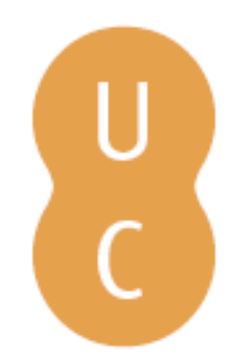

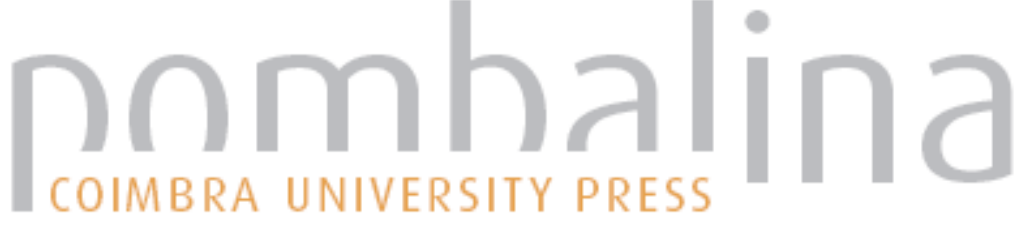

\section{Parental influences on youth sport participation}

Autor(es): $\quad$ Welk, Gregory J; Babkes, Megan L; Schaben, Jodee A

Publicado por: Imprensa da Universidade de Coimbra

URL

persistente: URI:http://hdl.handle.net/10316.2/32086

DOI: $\quad$ DOI:http://dx.doi.org/10.14195/978-989-26-0507-4_6

Accessed : $\quad$ 26-Apr-2023 11:06:10

A navegação consulta e descarregamento dos títulos inseridos nas Bibliotecas Digitais UC Digitalis, UC Pombalina e UC Impactum, pressupõem a aceitação plena e sem reservas dos Termos e Condições de Uso destas Bibliotecas Digitais, disponíveis em https://digitalis.uc.pt/pt-pt/termos.

Conforme exposto nos referidos Termos e Condições de Uso, o descarregamento de títulos de acesso restrito requer uma licença válida de autorização devendo o utilizador aceder ao(s) documento(s) a partir de um endereço de IP da instituição detentora da supramencionada licença.

Ao utilizador é apenas permitido o descarregamento para uso pessoal, pelo que o emprego do(s) título(s) descarregado(s) para outro fim, designadamente comercial, carece de autorização do respetivo autor ou editor da obra.

Na medida em que todas as obras da UC Digitalis se encontram protegidas pelo Código do Direito de Autor e Direitos Conexos e demais legislação aplicável, toda a cópia, parcial ou total, deste documento, nos casos em que é legalmente admitida, deverá conter ou fazer-se acompanhar por este aviso.

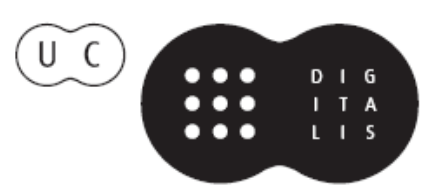


Manuel J. Coelho e Silva António J. Figueiredo Marije T. Elferink-Gemser Robert M. Malina
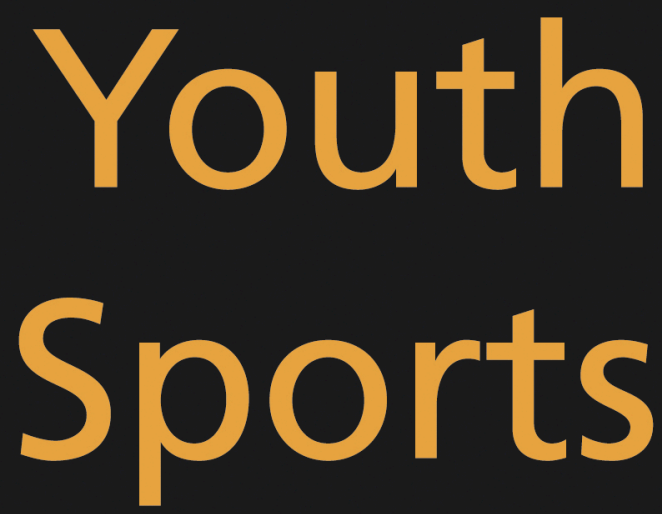

Participation, Trainability and Readiness 


\section{EDIC̣̃̃o}

Imprensa da Universidade de Coimbra

Email: imprensauc@ci.uc.pt

URL: http://www.uc.pt/imprensa_uc

Vendas online: http://siglv.uc.pt/imprensa/

\section{CONCEPÇÃO GRÁFICA}

António Barros

\section{EXECUÇÃo GRÁFICA}

Sereer, Soluções Editoriais

ISBN

978-989-8074-98-0

DEPÓSITO LEGAL

297937/09

OBRA PUBLICADA COM O APOIO DE:

FCT Fundação para a Ciência e a Tecnologia

MINISTÉrio DA CIÊNCIA, TECNOLOGIA E ENSINO SUPERIOR Portugal

Sub-projecto PRONTALSPORT 
Manuel J. Coelho e Silva António J. Figueiredo Marije T. Elferink-Gemser

Robert M. Malina

Editors

\section{Youth

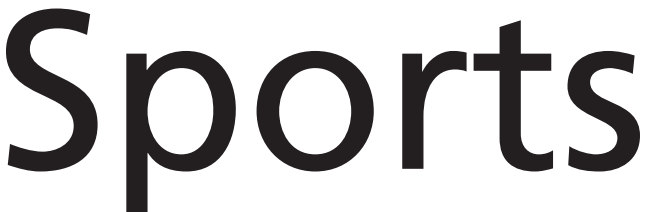 \\ Participation, Trainability and Readiness}


Part 1:

PARTICIPATION 


\title{
CHAPTER 6: PARENTAL INFLUENCES ON YOUTH SPORT PARTICIPATION
}

\author{
Gregory J Welk \\ Megan L Babkes \\ Jodee A Schaben
}

\section{INTRODUCTION}

Millions of children engage in physical activity and participate in competitive youth sport programs around the world. Involvement in these programs provides important health benefits and helps children learn physical skills that they can use throughout their life. Through the social interactions in sport programs children build friendships and learn important interpersonal skills such as cooperation and teamwork. Sport involvement also provides an opportunity for children to develop characteristics and values that may assist with academic or personal growth as they mature (e.g. perseverance, commitment, dedication). While there are many benefits associated with sports involvement, there are also some potential downsides. The emphasis placed on achievement in our society can put excess pressure on children to perform in sports and physical activity. Because not all children have equal motivation or genetic potential for success at sports, some may experience negative emotions or develop negative self-perceptions through their involvement in athletics. The inherent social evaluation or public display of ability in sports must be carefully considered to ensure that children develop positive perceptions and have healthy experiences through sport participation (Scanlan, 2002).

In the past twenty years, considerable attention has been focused on the impact that parents have on their children's sport and physical activity experiences and the psychosocial development associated with such involvement (Brustad et al., 200I). As a result, the knowledge base on the influence that parents have on young athletes is more comprehensive than ever before. This research consistently indicates that parents are critical agents in the process of children's sport socialization (Brustad and Partridge, 2002; Greendorfer et al., 2002). Mothers and fathers play a central role in the initial exposure of children to organized sport. They are generally the ones who seek out the opportunities, provide transportation, equipment and financial support. As children continue involvement in sport, parents not only maintain the provision of many resources, but also provide the necessary support and 
encouragement. Throughout this process, parents provide the primary source for filtering the meaning of sport experiences. Children come to believe in their abilities, have certain expectations of themselves and develop sportrelated value systems based, in large part, on the attitudes and behavior of their mothers and fathers.

The influence from parents can be positive and negative depending on how it is received and perceived by the child. Praise, encouragement and support can help to enhance a child's perception of their ability and increase their interest and involvement. Pressure and criticism, on the other hand, can damage a child's confidence and take the inherent enjoyment out of the activity. Often there is a fine line between pressure and support, and parents need to learn how to provide the right type and amount of assistance. Parental attitudes (e.g., beliefs and values) and behaviors (e.g., involvement with child or personal physical activity engagement) can also impact youth experiences both positively and negatively.

This chapter reviews the research on parental influences in youth sport and physical activity. The first section describes the predominant theories that have been used to study and understand parental influence in youth sports. The second section reviews various sources of parental influence that have been studied and highlights the impact they have on children's interest and involvement in sports. Particular attention is given to the types of influence that are grounded in socialization and developmentally based motivational theories. More descriptive forms of influence such as support, parental evaluation and the perceived meaning of athletic participation are also discussed. This section uses the described theoretical frameworks to more clearly describe the mechanisms through which parents influence children's attitudes and perceptions. The last section presents an integrative model of parental influence that incorporates elements from the different theoretical frameworks. The model is presented as a guide to understanding the complex nature of parental influences in sports and physical activity programs.

The majority of literature on parental influences in youth sport has typically been oriented toward social or psychological constructs of the young sport participants, e.g., stress or perceptions of competence, and the impact of various beliefs and behaviors of parents on the particular construct of interest (Brustad et al., 200 I; Brustad and Partridge, 2002). In this review, the focus is instead on the nature of the various forms of influence exerted by mothers and fathers, and subsequently how these impact children's sport experience, emotional responses, and beliefs systems. An important distinction with previous reviews is that sports participation is viewed as a means to an end rather than as an end in itself. In other words, the primary goal of youth sport programs should be to provide positive experiences and support so that the 
child develops an intrinsic interest in sports and physical activity. The guidelines and recommendations presented emphasize how parents can help children develop positive perceptions and values from sport and develop lifelong interest in sport and physical activity participation.

\section{THEORIES OF PARENTAL INFLUENCE}

Theories provide a way to interpret results from research and field experiences. With respect to youth sports, theories of motivation and sport socialization serve as both frameworks for research and guides for planning and delivering programs. Research eventually accumulates to support or refute a given theory, and the collective information can then serve to guide practice.

This section reviews different theories used to explain motivation in youth sports. While the theoretical frameworks differ in a number of significant ways, they also share many common elements. Emphasis is placed on the commonalities among theories since this probably provides the best basis for enhancing the delivery of youth sport programs. Four theoretical frameworks are emphasized: competence motivation theory (Harter, 1978, 198I), attribution theory (Weiner, 1974, 1980), achievement goal theory (Nicholls, 1989), and expectancy-values theory (Eccles et al., 1983).

\section{COMPETENCE MOTIVATION THEORY}

Competence motivation theory (Harter, 1978, 1981) is based on the notion that individuals have an innate need to experience feelings of competence. Competence can be achieved through mastery experiences in a variety of achievement situations but the child's perceived competence in a particular achievement situation or skill is the critical determinant. If the child feels competent, he/she will experience positive emotions and feelings, which will increase his/her intrinsic motivation or desire to participate in that sport or activity. If, however, the child does not feel competent in a specific situation, negative emotions can arise, anxiety is increased and motivation to participate is reduced. Competence and skill are both enhanced through repetition so that a critical factor for future motivation is willingness to engage in continued mastery attempts. If motivation is reduced, the child either does not pursue such mastery attempts or extrinsic motivation is necessary to continue involvement.

A major strength of competence motivation theory is that both socialization and developmental explanations of the psychological, emotional and motivational outcomes of children are considered. Studies on the sources 
of competence information for youth athletes (Horn and Amorose, 1998; Horn and Hasbrook, 1986, 1987; Horn and Weiss, 1991) have established that there is a developmental shift in the salience of significant others as a source of determining ability by children and adolescents. Prior to about 12 years of age, children tend to use feedback and reinforcement from parents and other significant adults (e.g. coaches) as the most important input in determining their own level of athletic competence. During early adolescence, the child looks less to the "authority" and develops self-perceptions based more on peer comparison and peer evaluation. With progress to late adolescence, perceptions of competence become more self-referenced. The adolescent now looks at the effort they exerted, level of attraction to the sport, as well as their personal goals and goal orientations. Therefore, there is a developmental shift from external sources to internal sources of information on which self-perceptions of ability are made. The transition to more external or peer-comparisons to assess competence is a normal developmental stage that occurs in concert with other cognitive and social stages.

\section{ACHIEVEMENT GOAL ORIENTATION THEORY}

The major contention of achievement goal theory is that individuals engage in an achievement situation to demonstrate competence (Duda, 1992; Nicholls, 1984, 1989). A distinction of this theory is that one's conception of competence is thought to be perceived differently depending on the goal orientation of the individual within the activity. The goal of an individual is related to his/her definition of success and subsequent achievement behavior. Two orthogonal goal orientations exist, ego and task. An individual may score high or low on both, or high on one and low on the other. An ego-oriented goal is one where competence is based on outperforming others or having superior ability. In contrast, task goals reflect an orientation where competence is determined based on self-improvement, effort, and the mastery of a task (Nicholls, 1989).

Whether one is task or ego involved is determined by two factors, goal orientations (dispositional) and motivational climate (situational) (Ames, 1992). Goal orientations refer to the individual's tendency to be either task or ego involved. These dispositional orientations are assumed to be the result of childhood socialization experiences (Nicholls, 1989) and are seen as the precursor for exhibiting a particular goal orientation. The motivational climate in a particular setting can also influence task or ego involvement. These situational constraints, typically determined by rules or by significant others within the environment, establish criteria for success or failure that are either task or ego involved (Ames, 1992). These environmental factors can potentially alter the dispositional probabilities and influence motivations. 
Two types of climate exist, performance and mastery. Performance climate, focuses on ego involved criteria for success or failure while mastery climate encompasses task-involving criteria. Individuals are "predisposed" by their own goals towards a particular orientation, but it is the environment that surrounds that individual that can change the orientation. Significant others, such as parents, coaches, teachers and peers, in an athlete's life structure the motivational climate. If a parent praises the child for competence and success (placing the emphasis on competition above effort), the child infers a performance-oriented environment and typically will give low levels of effort, avoid challenges and eventually give up in achievement situations (Ames, 1992). This performance-oriented environment has been associated with higher levels of ego orientation (Ames and Archer, 1988), which leaves children evaluating themselves based on wins and losses. If on the other hand, parents and teachers foster an environment that is mastery-oriented, children will develop a higher task orientation and in turn, retain their intrinsic motivation, regardless of their level of ego-orientation. Duda (1997, p. 309) has suggested that high levels of task orientation are essential for youngsters to help motivate them over an extended period of time as well as give them motivation when their "normative ability is in jeopardy."

\section{ATTRIBUTION THEORY}

Attributions are reasons or perceived causes people give for the outcome of an event either related to them or others. Attribution theory states that people examine motivation based on attributions made about performances. Although Fritz Heider is considered the founding father of attribution theory, Bernard Weiner's work has made exceptional contribution to attribution research, most significantly in regard to attribution processes associated with achievement situations. Therefore, focus is on the model of attribution described by Weiner (1974, 1980).

The original attribution model (Weiner, 1974) focused on two dimensions, locus of control (internal or external) and stability (stable or unstable). An internal locus of control is associated with individual characteristics, such as ability or effort, whereas, external would be associated with influences outside the individual's control, such as luck or task difficulty. For stability, attributions associated with permanent, long-term explanations are labeled stable (e.g., ability or task difficulty) while attributions that are changing and variable are unstable (e.g., luck and effort). In 1979, Weiner added a third dimension, which was labeled controllability, and the original 'locus of control' dimension was renamed as locus of causality. 
Each of the three dimensions plays an important role in explanations for achievement outcomes. Most often athletes will use a self-enhancing justification to explain a given outcome. Therefore, success would generally be attributed to internal factors (typically a combination of ability and effort), whereas failure would be attributed to external factors such as task difficulty or luck (Robinson and Howe, 1989). The stability of attributions may vary depending on how consistently a team wins or loses. Little League baseball players who had consistently lost attributed the losses to ability, but teams who had consistently won attributed the wins to ability and did not see their ability as less when they lost (Roberts, 1975). Further, individual players attributed themselves to have exhibited high effort, but their other team members to have lower effort.

\section{EXPECTANCY-VALUE THEORY}

A framework that has been particularly useful in the study of parental influence is the expectancy value framework proposed by Eccles and colleagues (1983). This framework, based originally on social learning theory, takes a broad perspective by emphasizing the factors that underlie parental socialization efforts with children rather than the specific effects that their influence has on children. Parents are viewed as both interpreters and providers of experience for children. Thus, parents shape a child's interests, beliefs and self-perceptions by providing access to various experiences and by influencing the child's interpretation of these experiences. Parental socialization efforts are thought to be dependent on the parents' expectation for their child's success and the value that parents place on success in this behavior. Thus, if parents expect that their child can be successful and value his/her success in this behavior, they will be more likely to socialize their child to pursue and excel at this behavior.

The model has been particularly effective at explaining gender differences in socialization from parents. If parents have differential values and expectations for boys and girls in a particular domain they will be more likely to support and encourage their child to work hard in this area. Gender differences in parental socialization influence have been reported in both academic (Eccles et al., 1984) and sport domains (Eccles and Harold, 1991). The model has also been successfully applied to studies of children's physical activity (Brustad, 1993, 1996; Dempsey et al., 1993; Kimiecik et al., 1996; Kimiecik and Horn, 1998).

Recent research has integrated the Eccles framework within a broader Family Influence Model to examine the impact of parental beliefs on children's activity. They have demonstrated that parental beliefs are important predictors 
of children's activity (Kimiecik and Horn, 1998) and have documented that parental beliefs are influential only to the extent that children adopted the same belief system (Kimiecik et al., 1996). The framework provides a useful guide to understand the factors that influence the differential support and encouragement that parents may provide in physical activity and sport.

\section{SUMMARY OF THEORIES OF PARENTAL INFLUENCE}

Each of the theories provides an alternative view to explain factors that influence socialization process into youth sport and physical activity. Each theory addresses the issue from of a sllightly different angle, but there are a number of common elements. All of the theories place great importance on children's perception of competence or ability. This construct may be operationalized in different ways, but it is clear that children's self perceptions of their abilities is an important determinant of involvement and enjoyment in sports and physical activity. Another common element is that parents play an important role in shaping a child's attitudes and perceptions. Parents influence a child's perception of competence, goal orientations, and attributions a child makes about his/her ability.

\section{THE NATURE AND IMPACT OF PARENTAL INFLUENCE}

Considerable research has been conducted to examine the links between parents' beliefs and behaviors and children's psychosocial development in sport. The specific types of influence that parents have on their children in sport are numerous and diverse. Theoretically grounded and empirically based studies have identified particular parental beliefs and behaviors that are relevant to participation patterns, emotional responses, self-perceptions, and motivation of young athletes. Table I summarizes the sport-related parental influence research organized by the particular constructs which have emerged. Consistent with the focus of this book, the behaviors and beliefs of mothers and fathers that are related specifically to children's competitive athletic participation rather than more broadly to their physical activity involvement are emphasized.

\section{PARENTAL PRESSURE AND EXERTION}

Inquires of the pressure, expectations and the degree of intensity that mothers and fathers place on their children for sport achievement and involvement has generated considerable research. Overall, children's interpretations of the particular form of parental influence vary substantially. This variability, in turn, 
contributes to sport-related emotional and motivational outcomes. The forms of influence that have emerged include parental pressure, expectations, and directiveness.

Table I. Types of Parental Influence Studied in Youth Sport

\begin{tabular}{|c|c|}
\hline CONSTRUCT & REFERENCES \\
\hline I. Parental Exertion & $\begin{array}{l}\text { Babkes and Weiss (1999), Brustad (1988) Gould et al. } \\
\text { (1991), Hellstedt (1990), Leff and Hoyle (1995) Scanlan } \\
\text { and Lewthwaite (1984, 1986) } \\
\text { Averill and Power (1995), Eccles and Harold (1991), } \\
\text { Green and Chalip (1997), Power and Woolger (1994), } \\
\text { Scanlan and Lewthwaite (1984) } \\
\text { Averill and Power (1995), Power and Woolger (1994) }\end{array}$ \\
\hline $\begin{array}{r}\text { II. Parental Beliefs } \\
\text { About Competence } \\
\text { About value of competence } \\
\text { About appropriatenss of sport } \\
\text { participation } \\
\text { About goal orientations }\end{array}$ & $\begin{array}{l}\text { Babkes and Weiss (1999), Felson and Reed (1986), } \\
\text { McCullagh et al. (1993) } \\
\text { Eccles and Harold (1991) } \\
\text { Brown et al. (1989) } \\
\text { Duda and Hom (1993), Ebbeck and Becker } \\
\text { (1994). White (1996) }\end{array}$ \\
\hline 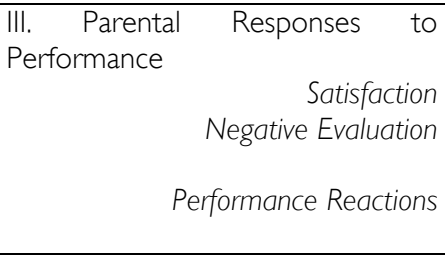 & $\begin{array}{l}\text { Scanlan and Lewthwaite (1986) } \\
\text { Brustad and Weiss (1987), Brustad (1988), Lewthwaite } \\
\text { and Scanlan (1989), Passer (1983), Weiss et al. (1989) } \\
\text { Babkes and Weiss (1999), Hellstedt (1990), Scanlan and } \\
\text { Lewthwaite (1986) }\end{array}$ \\
\hline $\begin{array}{r}\text { Encouragement } \\
\text { Support }\end{array}$ & $\begin{array}{l}\text { Scanlan and Lewthwaite (1986), Scanlan et al. (1989) } \\
\text { Babkes and Weiss (1999), Feltz et al. (1992), Ommundsen } \\
\text { and Vaglum (1991), Scanlan and Lewthwaite (1986) } \\
\text { Brown et al. (1989), Green and Chalip (1997) } \\
\text { Averill and Power (1995), Brown et al. (1989), Leff and } \\
\text { Hoyle (1995), Power and Woolger (1994), VanYperen } \\
\text { (1995). } \\
\text { Babkes and Weiss (1999), Brown et al. (1989), Power and } \\
\text { Woolger (1994), Wold and Anderssen (1992) }\end{array}$ \\
\hline
\end{tabular}

Parental pressure is a commonly discussed form of social influence in the pediatric sport psychology literature. Although there is no single consistent definition, the exertion of pressure by mothers and fathers has typically been conceptualized in a manner that reflects children's "perceived parental expectations, how critical parents are, their response to loss / defeat, parental concerns about winning, and the pressure parents put on them to succeed" (Leff and Hoyle, 1995, p. 192), or the "amount of motivational influence the parent exerts on the child-athlete to compete in sports, perform at a certain 
level and continue sport participation" (Hellstedt, 1990, p. 136). Regardless of exact definition, children have primarily responded to survey questions similar to those asked by Scanlan and Lewthwaite (1986) and (Brustad, 1988, p. 312): "My parents get upset with me when I do not play well," and "My parents think I should be a lot better in basketball than I am," to indicate the level of pressure that they perceive their parents exert.

The impact of perceived parental pressure has been examined in relation to an array of psychosocial outcomes, such as participation and motivation, but has mostly focused on the impact that perceived pressure has on emotional responses in sport (Babkes and Weiss, 1999; Brustad, 1988; Gould et al., 199I; Hellstedt, 1990; Leff and Hoyle, 1995; Scanlan and Lewthwaite, 1984, 1986). Young athletes who perceive high levels of pressure from their parents also experience higher levels of negative emotional responses. Lower levels of perceived pressure are consistently associated with more positive emotional responses to sport participation.

In an early, somewhat atheoretical, examination of sources of stressors among young athletes, Scanlan and Lewthwaite (1984) found that perceived parental pressure to participate in wrestling was predictive of pre-match stress among 9-14 year old males. Using the same questions to explore the impact of pressure, Gould et al. (199I) reported similar results. Perceived parental pressure to wrestle was a significant antecendent of pre- and post-match competitive state anxiety in early adolescent male wrestlers. In related research designed to test the relationship between significant others and affective responses to competence seeking endeavors in children, Brustad (1988) found that lower perceptions of parental pressure among male and female youth basketball players predicted high levels of season long enjoyment.

Research on parental pressure indicates that children perceive their mothers and fathers exertion of this form of influence differentially. In a study grounded within competence motivation theory, Babkes and Weiss (1999) found a disparity in perceived pressure based on parental gender. While perceptions of maternal pressure did not contribute significantly to the relationship between parental influence and male and female children's soccerrelated psychosocial outcomes, perceptions of lower paternal pressure to perform was associated with higher enjoyment, perceptions of competence and indicators of intrinsic motivation among young competitive athletes. In a study of young tennis players, Leff and Hoyle (1995) reported similar gender differences. Higher levels of pressure were attributed to fathers as compared to mothers for male players, whereas females perceived similar levels of pressure from mothers and fathers. Scanlan and Lewthwaite (1986) found higher levels of enjoyment among 9-14 year old male wrestlers associated 
with lower levels of perceived maternal pressure. The findings thus suggest that the impact of perceived parental pressure varies according to the gender of the parents and young athletes being assessed.

In a detailed examination, Hellstedt (1990) reported that over $70 \%$ of highly competitive young skiers expressed that their parents exerted moderate to forceful level of pressure to compete and not withdraw from sport. Consistent with other research, high perceived parental pressure was associated with negative affective reactions among both the male and female athletes. Although high levels of perceived parental pressure were more likely to elicit a negative emotional reaction, the author interestingly concluded that many athletes did not actually view this pressure as truly negative. In fact, some of the athletes expressed that the amount of pressure exerted by parents served as a form of support and was construed as positive in terms of enhancing their sport performance.

Parental expectations of their children's sport participation and performance are another frequently studied form of parental pressure. In the context of sport, expectations are conceptually similar to "pressure", but they are operationalized and interpreted differently. Expectations have generally been defined as "parents' specific performance goals or the extent to which parents want the child to become a successful athlete as opposed to being satisfied as long as child has fun" (Averill and Power, 1995, p. 168; Power and Woolger, 1994, p. 62).

Research on the impact of perceived parental expectations is equivocal. For example, Scanlan and Lewthwaite (1984) found that young male wrestlers who reported more frequent worry about meeting parental expectations experienced higher state anxiety prior to competition than peers who did not experience the same worries. Others, however, have found that young soccer players who perceived their parents to have high expectations for them in sport reported higher levels of perceived soccer ability and enjoyment (Averill and Power, 1995; Green and Chalip, 1997). Parental performance goals or expectations had a curvilinear relationship with children's enthusiasm and enjoyment in age-group swimming (Power and Woolger, 1994).

The data appear to indicate a threshold of perceived parental expectations. A moderate level of performance and success expectations is beneficial and related to positive sport-related responses. Expectations that are perceived as too high, or those that are accompanied by considerable worry about meeting parental hopes and dreams, may in fact be detrimental to social, emotional or psychological responses experienced by youth athletes. 
The influence of expectations appears to differ depending on whether they come from mothers or fathers. Maternal performance expectations were positively associated with young children's soccer enjoyment, while fathers' expectations or performance goals were negatively associated with their ratings of their child's effort (Averill and Power, 1995).

Research grounded in theories such as the expectancy-value theory provides a way to understand and predict the impact of parental expectations on young athletes. Findings from a three year longitudinal study of the relationship between parental beliefs and children's self-perceptions and activity choices revealed that perceptions of parental expectancies were significant predictors of children's perceptions of competence. Perceptions of competence, in turn, were related to the choices that children made in choosing to participate or not participate in particular activities. More specifically, children who perceived that their parents thought they were athletically competent and expected them to choose to play sports believed that they were able in sport and subsequently chose to be involved in athletics. Further research is needed to expand our understanding of the critical role that parental expectations play in children's athletic involvement.

Parental directiveness is defined as the "degree to which parents actively instruct their child about how to approach achievement tasks with an emphasis on areas in need of improvement " (Averill and Power, 1995, p. 268; Power and Woolger, 1994, p. 62). It has been the focus of some research on the social exertion that young athletes receive from their parents. Parents who engage in directiveness typically tell their children what to do whether it is solicited or not. A statement such as "Before a meet, I remind my child of what he/she needs to work on," would be indicative of high directiveness, while a statement such as "I give my child advice about how to improve in swimming only when he/she asks for it," is an example of low directiveness.

Too much or too little parental directiveness is associated with low levels of sport enjoyment and effort. The impact, however, may differ by parental gender. Paternal directiveness was highest when children's effort and ability was low, but maternal directiveness was not associated with children's psychosocial outcomes (Averill and Power, 1995). Reported parental directiveness had a curvilinear relationship with enjoyment among age-group swimmers of both sexes (Power and Woolger, 1994). Apparently, the impact of the amount of mother- and father-imposed directiveness is similar to the amount of perceived expectation in terms of how beneficial or detrimental these forms of influence are on young athletes.

It appears that the interpretations and perceptions of parental pressure, expectations and directiveness by young athletes are related to their 
experiences in the sport. Further research is needed to determine the degree to which these forms of influence should be encouraged and/or curtailed among parents so that children engage in sport in a psychosocially healthy manner.

\section{PARENTAL BELIEF SYSTEMS}

Through the assessment of various types of beliefs, research overwhelmingly suggests that children's interpretation of their parents' beliefs about competence, or how success is demonstrated, that matters with respect to psychological, social or emotional responses. Parental beliefs about their child's athletic competence or ability, relative value of sport participation, achievement goal orientations, and perceived appropriateness of athletic involvement are specific forms of influence that have emerged from this domain of study.

With little exception, exploration into the relationship between parental beliefs about children's sport ability and children's own perceptions of athletic competence has been grounded in competence motivation theory. Findings from two studies provide strong support for the utility of this framework as a useful way to understand parental influence in sports. McCullagh et al. (1993) found a correspondence between parental perceptions of their children's soccer competence and the young athlete's own ratings of ability in soccer. Babkes and Weiss (1999) noted a positive association between higher perceptions of parental beliefs about soccer competence and children's perceptions of soccer ability, soccer enjoyment and intrinsic motivation.

Felson and Reed (1986) examined the influence of parental belief systems on children's own self-perceptions from a reflected appraisal approach (Mead, 1934; Cooley, 1902). The findings were consistent with subsequent research in that parental appraisals had an effect on $4^{\text {th }}$ through $7^{\text {th }}$ grade children's self-appraisals of how well they did at sports. There was a differential influence between the impact of mothers and fathers on children's selfappraisals of sport ability. These results possibly reflect a developmental change in social influence. Younger athletes expressed that they perceived equal levels of perceived parental appraisal in ability when comparing mothers and fathers. Among older children, however, mothers maintained a significant influence with sons, but declined with daughters. Fathers' influence over daughters' self-reflected appraisal increased. These findings suggested that there was greater cross-sex influence in older children when considering parental appraisals of children's appraisals of their own ability. 
The value that mothers and fathers place on being competent in sport is another parental belief system that has been examined. In Eccles and Harold's (|99|) study, a large sample $(\mathrm{n}=875)$ of children answered survey questions focused on "how important they thought it was to their parents that they do well in sports, math and English," and "whether ability in each area was more important for boys, for girls, or both" (p. 24). The findings from this study, which was grounded in expectancy-value theory, revealed that boys thought it was not only more important to their parents that they do well in sports than girls, but they also thought it was more important to their parents that they participate in sport than girls.

Eccles and Harold (1991) concluded that the extent to which male and female children thought their parents valued sport competence was directly related to the level that they rated their own sport competence. Children's views of the importance that their parents attach to involvement in sport related to their own sense of athletic ability. Children who believe that their parents think it is important for them to do well in sports, rate their own ability in sport as being higher. Essentially, perceptions of parents' expectancies and values were significant predictors of children's own value and ability beliefs. These findings further help to explain why children chose to participate in the activities they engage in.

Parental beliefs about how acceptable sport participation is for males and females is another form of influence. The premise in this line of research is that physical endeavors have been viewed as more masculine in nature and this attitude is maintained when parents consider appropriate sport participation for their children. Participation by adolescent Canadian females in intramural, interschool and community sports, for example, was associated with the girls' perceptions that their fathers viewed sport as an "appropriate" activity for them (Brown et al., 1989). The view that parents, especially fathers, have about the appropriateness of daughters' activity choices appears to have an impact on continued involvement in sport. Although this particular study was not grounded in a particular theoretical framework, the findings are consistent with the contentions of Eccles et al. (1983) regarding the effects of value socialization on activity choice behavior. Continued research is necessary to fully understand the dynamic nature of how parents convey their beliefs about appropriate and valuable endeavors to their children.

A number of studies have supported the utility of goal achievement theory and examined the influence of parents' beliefs about success, or goal orientations, has on children's sport involvement. Children tend to adopt similar belief systems about success in sport as those of their parents. Ebbeck and Becker (1984), for example, found that parental goal orientations were dominant predictors of player goal orientations. Specifically, player task and 
ego orientations could be predicted by whether they perceived their parents to define success in self-referent or norm-referent terms. Level of task orientation of young soccer players was predicted by their own perceptions of competence and, more importantly, by perceiving that their parents had a high level of task orientation. Athletes who perceived their parents to have a high ego orientation were likely to believe that success was demonstrated in a norm-referenced manner.

Duda and Hom (1993) also found that the goal orientations male and female summer basketball camp participants were related to their views concerning the goal orientations adopted by their parents or how their mother or father defined success and judged competence in sport. High task oriented children perceived their parents to be more task oriented and high ego oriented children perceive their parents to be more ego oriented.

White (1996) extended the previous research on goal orientations among parents and their children and explored the parent-initiated motivational climate among adolescent female volleyball players. Results revealed that athletes who perceived that their parents emphasized success without effort were more ego oriented in their beliefs about success in sport. Athletes who were more task oriented, however, perceived their parents as fostering a climate that focused on learning and enjoyment.

Overall, perceptions of what parents believe about their child's ability and the value or appropriateness that they convey regarding athletic participation seem to be similarly believed by young athletes. The beliefs that parents convey about the goals of participation and how success should be determined are also consistently related to athlete's orientation toward participation and performance in sport. More research is necessary to thoroughly comprehend how this correspondence in parent-child beliefs is created and maintained.

\section{PARENTAL RESPONSES TO PERFORMANCE}

Responses of parents to their children's sport performances are another form of influence. Presently available evidence suggest that children's perceptions of their parents' responses and the contingency of parental reactions to performance are directly related to psychosocial outcomes in sport. The more favorable and contingent the parental response, the more young athletes are likely to report enjoyment and less stress.

Only two studies to date have attempted to actually examine perceived parental satisfaction with youth sport performance. In studies of competitive 
young male wrestlers, Scanlan and Lewthwaite $(1984,1986)$ assessed whether stress and enjoyment were predicted by perceived parental satisfaction with their season long performance. Although parental satisfaction did not emerge as a factor related to stress, greater perceived parental satisfaction with season performance was associated with higher levels of sport enjoyment.

Children's perceptions that parents would evaluate their performance negatively, or not express satisfaction in response to their demonstration of sport ability, have also been examined. Worry about potential negative parental evaluation is the construct that has most often been assessed. Worry of this kind is consistently associated with unfavorable emotional responses, such as stress or anxiety. Brustad and Weiss (1987), for example, found that young male baseball players who were high in competitive trait anxiety were more likely to have a high frequency of worry about incurring negative evaluation from their parents in the event of a poor performance compared to their less anxious peers. Brustad (1988) noted that male and female basketball players who were more competitively trait anxious worried more about receiving negative evaluations from others, such as parents. The highly anxious young athletes also perceived worry about evaluation as emotionally aversive.

Weiss et al. (1989) examined the relationship between precompetition anxiety among competitive male gymnasts and worry about negative social evaluation as well. Results revealed that the athletes' most worrisome precompetition thoughts were related to concern over receiving negative evaluation based on their performance from their parents. The two specific worries were, "what my parents will think" and "letting my parents down". Worry over anticipated negative evaluations from parents has consistently been associated more often with children who are highly trait anxious in competitive situations (Brustad, 1988; Lewthwaite and Scanlan, 1989; Passer, 1983). Therefore, the perception of frequent negative evaluations from parents and the subsequent impact on young athletes' sport experiences may, in fact, be mediated by children's disposition.

More general parental reactions to performance or responses contingent on the performance of young athletes has also been examined. For most part, these reactions have been described in the context of "...the affective and behavioral reactions demonstrated by parents following children's display of sport ability" (Babkes and Weiss, 1999, p. 49). Using this operational definition, there was a positive relationship between perceptions of mothers and fathers provision of frequent positive performance contingent responses to performance success and competitive soccer players psychosocial responses. The findings are consistent with previous results that young competitive male wrestlers who reported fewer negative maternal 
performance reactions experienced more enjoyment (Scanlan and Lewthwaite, 1986).

\section{PARENTAL BEHAVIORS}

The impact of parental behaviors on children involved in sport has also been studied. Parental behaviors include interactions, involvement, encouragement, support, and role modeling. Most of these behaviors appear to be perceived by children as positive in nature and have thus been considered to enhance the psychosocial outcomes and development of youth involved in sport. The most general forms of parental behavior that are likely to impact children's achievement pursuits are interactions which occur between parents and their children. To date, Scanlan and Lewthwaite (1986) and Scanlan et al. (1989) have explored parent-child interactions in the context of sport in young wrestlers and elite figure skaters, respectively. A lower frequency of negative maternal interactions perceived by young competitive male wrestlers was predictive of higher sport enjoyment. And, among former elite figure skaters, athletes experienced enjoyment as a result of bringing pleasure and pride to family through their sport achievement and engagement. The results suggest that an athlete's ability to use sport as a mechanism for creating positive interactions with significant others is an important source of enjoyment for them. Although these findings intimate that parent-child interactions have the potential to optimally impact youngsters' sport experiences, further research is warranted to more thoroughly understand the range of nature of this interplay.

Parental involvement in children's athletic endeavors has been examined more thoroughly than parent-child interactions. Involvement has been defined as "the extent to which parents took part in their child's sport participation either directly (i.e., giving instruction) or indirectly (i.e., attending games)" (Babkes and Weiss, 1999, p. 49), or as "encouragement, rearrangement of the family schedule to accommodate running, took them to practices and meets, attended practices and meets, gave them advice/instruction and inquired about their progress" (Feltz et al., 1992, p. 130).

Findings suggest that children who perceive that their mothers and fathers are highly engaged in their sport activity tend to report more positive emotional responses and higher levels of perceived competence and motivation. For example, young male wrestlers who reported more involvement from adults, such as parents, enjoyed competitive wrestling (Scanlan and Lewthwaite, 1986), and the enjoyment of adolescent Norwegian 
soccer players was positively related to perceived emotional involvement of their parents (Ommundsen and Vaglum, 1991).

In one of the only longitudinal studies of parental influence, Feltz and colleagues (1992) observed no differences in perceptions of parental involvement by adolescent male and female distance runners. The degree of maternal versus paternal involvement, however, was perceived to be different. The runners expressed that fathers were more involved, i.e., attending races and showing interest, in their running than were mothers. Additionally, the amount of parental involvement in the adolescents' competitive running was perceived to decrease over time and with age in both males and females. Babkes and Weiss (1999) more recently found support for the perceived differential impact of maternal and paternal involvement. Athletes whose fathers were perceived as being more involved in their children's soccer, had more positive psychosocial responses. Maternal involvement did not significantly impact motivation, enjoyment or perceived competence of the children.

The encouragement provided by mothers and fathers for children's sport performance and involvement is another important behavior. The receipt of parental encouragement has been associated with positive athletic experiences for youth. Green and Chalip (1997) found that higher perceptions of parental encouragement among young male and female soccer players had a significant effect on children's satisfaction and involvement in soccer. Brown et al. (1989) found that the higher the encouragement that girls perceived from their parents, the more continuity they maintained in intramural, interschool and community sport involvement.

Parental support is another frequently studied behavioral construct that has been operationalized in several ways. One commonly used definition is as follows: ". . . providing emotional support for child's soccer playing regardless of performance" (Averill and Power, 1995, p. 168; Power and Woolger, 1994, p. 62). A number of studies have examined the correlates of perceived parental support to determine the effect on sport-related outcomes and behaviors. Maternal support was positively related to level of enjoyment for soccer among their sons (Averill and Power, 1995). Parental level of support was also positively related enthusiasm among age group swimmers of both sexes (Power and Woolger, 1994). Among adolescent girls higher perceptions of support for involvement in sport, especially as they grew older, were associated with stronger continuity of sport participation (Brown et al., 1989). Support for involvement from fathers in particular was a significant predictor of the sustained athletic involvement among these adolescent females. For young male and female tennis players, perceived parental support was associated with higher levels of enjoyment and self-esteem (Leff and Hoyle, 
1995). Among elite male soccer players, when perceived parental support was low, the players experienced more negative feelings about the team following low performances (Van Eyperen, 1995). In other words, the players did not suffer from as much interpersonal stress following a poor game when they felt that their parents were more supportive. Results of this series of studies suggest that parental support serves to "buffer" the effects of interpersonal stress when a negative performance occurs and enhances the overall positive experiences for children involved in athletics.

Parental role modeling has repeatedly been related to children's sport participation. Studies suggest that children whose parents took part in sport or physical activity were more likely to take part in athletics themselves. Couched within a socialization theory perspective, Wold and Anderssen (1992) found that among European schoolchildren sport participation of similar sex family members was more strongly associated with their sport participation than the opposite sex, while Brown et al. (1989) reported that mother's role modeling or same sex participation in sport was a significant predictor of continued athletic involvement by adolescent females. Babkes and Weiss (1999) found that competitive male and female soccer players who perceived their mothers and fathers as more positive role models through their own physical activity reported more enjoyment, higher perceptions of competence, and more intrinsic motivation.

As with other social influence constructs, the impact of role modeling behaviors appears to have a differential effect depending on the gender of the parent and the child. In a study of age-group swimmers and their parents, Power and Woolger (1994) found a positive relationship between mothermodeling and sport enthusiasm among both males and females. There was, however, a negative association between father modeling and enjoyment among male swimmers.

\section{SUMMARY OF PARENTAL INFLUENCE IN SPORT}

In summary, parents who provide more support or encouragement, respond positively when it is contingent with performance, model active lives, believe that their children are athletically competent, and exert lower levels of pressure or expectations have children who worry less, experience more enjoyment, believe they are capable in sport and are intrinsically motivated in their sport endeavors. In contrast, parents who exert high levels of expectations and pressure, respond negatively to performance, interact poorly, believe that their children are not particularly able in sport and do not model active lives are more likely to have children who experience more stress, less 
enjoyment, believe they are less competent, more extrinsically motivated, and more likely to cease participation.

It is the young athletes' perceptions of parental influence that matters most with regard to healthy sport experience and psychosocial development. Children's' perceptions of parental attitudes and behaviors are more strongly related to children's enjoyment, perceptions of competence, and motivation than parental reports of their own influence (Babkes and Weiss, 1999). In other words, regardless of how supportive or how little pressure parents think they place on their children to achieve success in sport, children may interpret events and beliefs differently. While these findings may seem to place mothers and fathers at a loss for how to actually parent their children effectively in pursuit of sport achievement, the results indicate the importance of understanding how parents and children communicate to bring about healthy sport experiences. Research to date, however, has yet to thoroughly understand the dynamics of communication patterns between parents and their children involved in sport.

It is also important to distinguish the differential influence of mothers and fathers on their children, and more specifically how this may differ for boys and girls. Although a few studies have focused on the relative influence of each parent, the majority of findings summarize the combined influence of both parents rather than the separate or differential influence. In addition to recognizing the changing structure of family, Greendorfer (2002) recently highlighted the extent of the difference that mothers and fathers conceivably have on their children's sport socialization. The nature of the effect that dominant gender ideology has historically had on both the sport socialization of females and the role that mothers play in their children's sport endeavors are changing. Historically, salient maternal influences have include support, encouragement, and more nurture-related forms of influence, but increasing trends in maternal employment might result in changes with respect to how mothers and fathers, respectively, contribute to their children's achievement. Furthermore, the potential changes in parenting roles may also result in changes in children's gravitation toward sex-typed activities given the alteration on gender-related patterns of engagement by their mothers and fathers. Given that sport is often perceived as more valuable and expected among males and that females are still more frequently exposed to activities that accentuate qualities that are "feminine", understanding the relative influence of mothers and fathers on the sport experiences of both young males and females is an important direction for future research.

Understanding parental influence in youth sport is limited by the lens with which this topic is viewed. The majority of research has been conducted on Caucasian, two-parent families of primarily middle and upper 
socioeconomic status where the youth sports participants are able-bodied and without cognitive deficits. The lack of diversity in the extant research inhibits the ecological validity of the findings to a broader array of families involved in the athletic arena. To date, data are not available about the parent-athlete relationship in single parent families, for those of relatively low socioeconomic status, or for the child with physical or cognitive limitations who is involved in sport.

\section{AN INTEGRATIVE MODEL OF PARENTAL SOCIALIZATION INFLUENCE IN SPORTS AND PHYSICAL ACTIVITY}

This section describes an integrative model that summarizes the processes involved in youth activity promotion. The model is based on the conceptual framework previously described as the Youth Physical Activity Promotion Model (Welk, 1999). The model is expanded to describe more specifically how and why parents socialize their children into sport and physical activity (Figure I).

Youth Physical Activity Promotion Model (Welk, 1999)

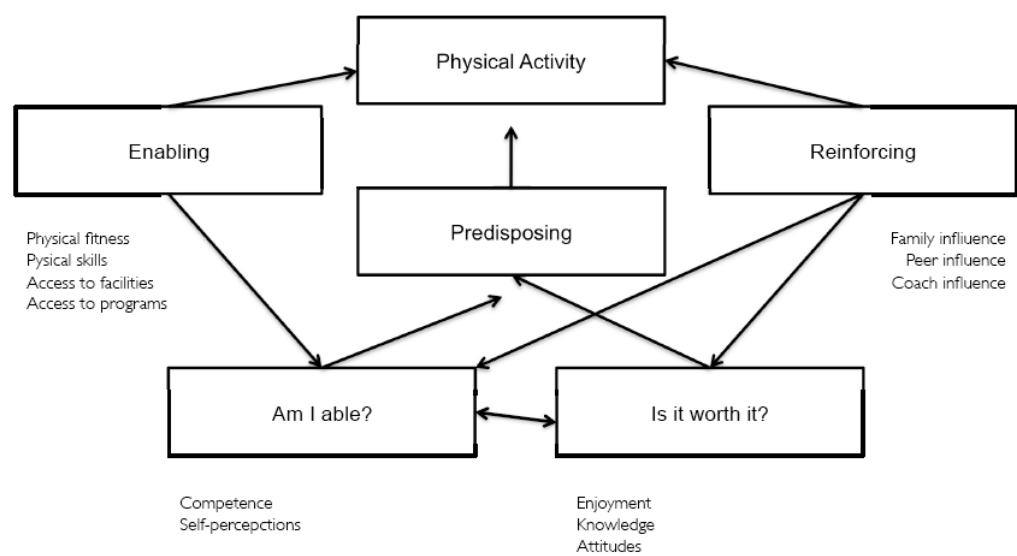

Figure I. Youth Physical Activity Promotion Model

A basic premise in the model is that parents influence children both directly and indirectly. Direct effects may be through involvement or facilitation of a child's efforts or involvement. Parents enroll children for sports and provide 
the equipment, transportation and financial support to continue being involved. Parents also indirectly influence a child's interest and involvement in sports and activity. In this model, it is proposed that this effect is mediated through two distinct social-cognitive based constructs, outcome expectancies and efficacy expectancies. These two constructs are operationalized as "Is it worth it?" and "Am I Able?". To maintain interest and involvement in sports and physical activity, children need to be able to answer both questions in the affirmative. If children believe that sports are "worth it", but they are not skilled enough to participate they are not likely to participate. Similarly, if children feel competent in an activity but do not find that their involvement is worthwhile, they will not maintain involvement.

Consistent with the expectancy-value framework (Eccles et al., 1983), it is proposed that the degree of parental socialization influence is determined by the values and expectancies parents have with regard to sport and physical activity. Parents with more favorable values and expectancies are more likely to model appropriate activity behavior, promote involvement, and provide necessary social support and encouragement (Figure 2). The impact of these socialization efforts, however, depends on how they are perceived or internalized by children. Those who perceive positive values and expectancies from their parents are more likely to develop more positive perceptions of competence and to be more attracted to sport and physical activity. On the other hand, children who perceive more negative values and expectancies are more likely to have poorer perceptions of competence and may lose interest in sport and activity.

The principles derived from competence motivation, attribution, and achievement motivation theories should serve as a guide for how to provide feedback, instruction and support to children in the sport and physical activity settings. Several examples are subsequently considered. 


\section{Integrative Model of Parental Socialization Influence}

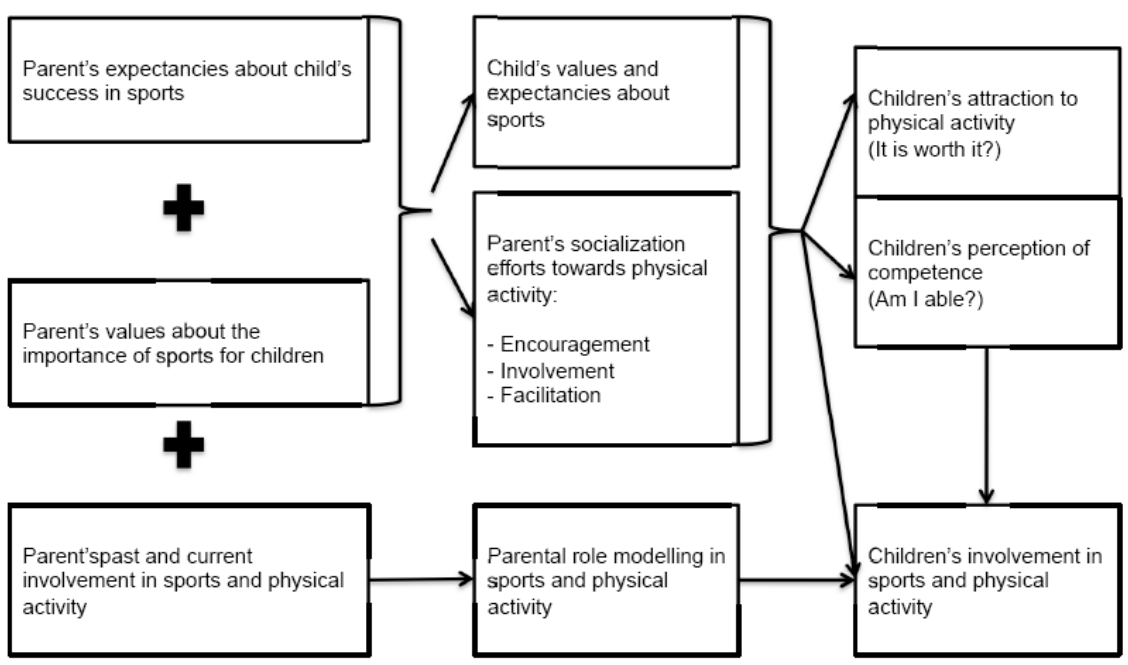

Figure 2. Integrative Model of Parental Socialization Influence

\section{APPLICATION OF COMPETENCE MOTIVATION THEORY}

Information and feedback that helps a child to build high perceptions of competence should be provided in order to enhance the child's interest and involvement in sport. Perceptions of competence are the central determinant of interest and involvement but the nature and source for establishing this selfassessment change over time. Children clearly depend on their parents for the initial interpretations of their experiences. It is these interpretations which are relayed to the child and impact their self-perceptions. With regular encouragement and support, children remain intrinsically motivated and can make a normal shift from external information to internal information on which to base their self-perceptions. How a parent responds to the initial mastery experience can influences how competent the child feels in that particular setting and shape their emerging self-perceptions. An example of two different parent-child interactions is provided below for illustration purposes. 
Sarah is a third grader and decides to play basketball. The following two scenarios illustrate how the same event could have different consequences and effects depending on the type of parent-child interactions.

Scenario I: During the first game her parents are watching, cheering, and smiling. When the game is finished her mother says to her "Sarah you did a great job out there. We sure enjoyed watching you play." Her father greets her with a hug and says, "That's my girl. Did you have fun? Maybe we could get a hoop at home and play together." The support and encouragement that her parents showed sends her the message that they think she is competent and has a natural ability for playing basketball. It also shows her that they are interested in her activities.

Scenario 2: During Sarah's first basketball game, Sarah's parents spend the entire game reading the paper and discussing the weekend plans. When the game is finished Sarah's mom says, "Come on Sarah. We have to go. We have groceries to get and now you have to have a bath before bed too." The dad walks over and picks up her jacket and says, "I am not sure I saw you dribble or make a good shot the entire game. Are you afraid to get in there and get tough?"' In this situation, support or encouragement are lacking; the mom is hurrying off to the grocery store and the dad thinks she is not tough enough to be a basketball player. This tells Sarah that she lacks ability, or is not competent, in basketball and that her parents are not interested.

\section{APPLICATION OF ACHIEVEMENT GOAL ORIENTATION THEORY}

According to goal orientation theory, emphasis should be placed on fostering a task goal orientation towards sports and physical activity. Sport activities in western society, however, clearly lend themselves to an ego orientation. Sports generally include achievement situations in which there is formal evaluation and the outcome is generally of importance to parents. Children are also stratified by ability in most sports and their perception of ability is frequently tied to a normative (peer) comparison. To counter this potential for ego orientation, it is important to establish an environment and climate in which children experience sport from a mastery or task orientation. Emphasis should be placed on personal improvement and effort. Success then becomes associated with learning, effort, and personal improvement as opposed to winning or beating a particular team. With this orientation, success becomes something they can control, enjoy and expect because it has only to do with them and does not involve the evaluation and control of someone else's performance. Parents, often without realizing, reveal their orientation to the 
child by the questions they ask or the information that they seek. Examples of two interactions are provided below for illustration purposes.

Background: John comes home from a soccer game and his parents ask him a few questions about the game after dinner.

Scenario I: The first question the parent asks is, "Did you win?" This shows that the parent is mainly interested in the outcome of the game and not what happened within the game. John learns that this is the important result and begins to adopt an ego-oriented focus with his involvement in sports.

Scenario 2: The first question the parent asks is "How did you play?" "Did you get a chance to head the ball? How did that go?" In this scenario, the parent is interested in the child's ability to improve their skills (to head the ball) and improve their game as a whole. The child focuses on how it felt to participate in the game rather than the outcome of the game. This helps the child adopt a task-orientation in sports.

\section{APPLICATION OF ATTRIBUTION THEORY}

Attribution theory suggests that feedback should help children to focus on effort (unstable) as opposed to ability (stable) when taking responsibility for a failure. The long-term consequences of attributing a loss to ability is that failing players consider themselves to be low in ability and therefore see little hope for future success. This can result in the athlete exhibiting "learnedhelplessness", in which the success is viewed as out of their control. Athletes in this state view their efforts as irrelevant; they may give up easily or drop out of the sport all together. Fortunately, it has been shown that, with the help of parents and coaches, athletes can adjust their thinking to associate a failing situation with effort and not ability.

Too often, children are taught to take responsibility for the outcomes (whether they are good or bad) and the child comes to believe that they can always change and impact the outcome. Attributions are created most typically in novel situations or situations with unexpected rather than expected events. Once there are previous experiences to look back to, the attributions are typically made based on previous determinations. Parents and coaches play a critical role in helping children to interpret new experiences with the appropriate orientation. They can clearly help a child learn when the outcome was in their control. It is what parents say and do immediately following a loss 
that may have a great impact on how the child attributes and explains the loss. An example of the application of attribution theory is provided below.

Volleyball is being offered as a new junior varsity sport. Kelly decides to tryout. After making the team, the team loses their first two games.

Scenario I: After the second loss, Kelly's parents explain, "If you could get to the ball more quickly and actually get into the air to get the ball over the net, your team would have won both games but you just don't have the speed, lower body strength or height to play close to the net. Kelly concludes that she does not have the ability to play volleyball and there is nothing she can do about her performance or the outcome of the game.

Scenario 2: After the second loss, Kelly's parent's explain, "It is just a matter of hustle. You are a new team learning to work together and if you, as well as the rest of the team, could work more quickly to get into position and begin to understand what the other team members are doing you will begin to win games." Kelly has learned that she has some control over this situation and the outcome of the game can be changed with a little hard work.

\section{SUMMARY}

The social nature of competitive sport and the emphasis placed on achievement in society make the relationship between parents and their children a critical element in the healthy development of young athletes today. Although further research on the nature and impact of various forms of parental influence is needed, a solid knowledge base exists to help mothers and fathers positively impact children's sport endeavors. What parents expect, the pressure they exert, the beliefs they maintain, the way they respond to performance, and the behaviors they engage in affect the lives of young sports participants. This information should be used to construct youth sport environments and experiences that enhance children's overall sport experience. New challenges for researchers are to examine the dynamic nature of parent-child interactions in the sport arena so that practitioners can continue to use this information more effectively.

\section{REFERENCES}

Ames C (1992). Achievement goals, motivational climate, and motivational processes. In GC Roberts (Ed). Motivation in sport and exercise (pp. I6I-I76). Champaign, IL: Human Kinetics. 
Ames C, Archer J (1988). Achievement goals in the classroom: Students' learning strategies and motivational processes. Journal of Educational Psychology, 80(3), 260267.

Averill PM, Power TG (1995). Parental attitudes and children's experiences in soccer: Correlates of effort and enjoyment. International Journal of Behavioral Development, 18, 263-276.

Babkes ML, Weiss MR (1999). Parental influence on children's cognitive and affective responses to competitive soccer participation. Pediatric Exercise Science, I I, 44-62.

Brown BA, Frankel BG, Fennell MP (1989). Hugs or shrugs: Parental and peer influence on continuity of involvement by female adolescents. Sex Roles, 20, 397409.

Brustad RJ (1988). Affective outcomes in competitive youth sport: The influence of intrapersonal and socialization factors. Journal of Sport and Exercise Psychology, 10 , 307-321.

Brustad RJ (1993). Who will go out and play? Parental and psychological influences on children's attraction to physical activity. Pediatric Exercise Science, 5, 210-223.

Brustad RJ (1996). Attraction to physical activity in urban schoolchildren: Parental socialization and gender influences. Research Quarterly for Exercise and Sport, 67(3), 316-323.

Brustad RJ, Babkes ML, Smith AL (200I). Youth in sport: Psychological considerations. In RN Singer, HA Hausenblas, CM Janelle (Eds.), Handbook of sport psychology $\left(2^{\text {nd }}\right.$ ed., 604-635). New York: John Wiley and Sons.

Brustad RJ, Partridge JA (2002). Parental and peer influence on children's psychosocial development through sport. In FL Smoll, RE Smith (Eds.), Children and youth in sport: A biopsychosocial perspective ( $2^{\text {nd }}$ ed., pp. 187-210). Dubuque, IA: KendallHunt Publishing.

Brustad RJ, Weiss MR (1987). Competence perceptions and sources of worry in high, medicum, and low competitive trait-anxious young athletes. Journal of Sport Psychology, 9, 97-105.

Cooley CH (1902). Human nature and the social order. New York: Scribner's.

Dempsey JM, Kimiecik JC, Horn TS (1993). Parental influence on children's moderate to vigorous physical activity population: an expectancy-value approach. Pediatric Exercise Science, 5, 151-167.

Duda JL (1992). Sport and exercise motivation: A goal perspective analysis. In G Roberts (Ed). Motivation in sport and exercise (57-9I). Champaign, IL: Human Kinetics.

Duda JL (1997). Perpetuating myths: A response to Hardy's 1996 Coleman Griffith address. Journal of Applied Sport Psychology, 9(2), 303-309.

Duda JL, Hom HL (1993). Interdependencies between the perceived and selfreported goal orientations of young athletes and their parents. Pediatric Exercise Science, 5, 234-24l.

Ebbeck V, Becker SL (1994). Psychosocial predictors of goal orientations in youth soccer. Research Quarterly for Exercise and Sport, 65, 355-362.

Eccles-Parsons J, Adler TF, Futterman R, Goff SB, Kaczala CM, Meece JL, Midgley C (1983). Expectancies, values, and academic behaviors. In J Spence, R Helmreich (Eds). Achivement and achievement motives: Psychological and sociological approaches (75-146). San Francisco: Freeman.

Eccles J, Adler TF, Kaczala CM (1982). Socialization of achievement attitudes and beliefs: Parental influences. Child Development, 53, 310-321. 
Eccles J, Adler TF, Meece JL (1984). Sex differences in acheivement: A test of alternate theories. Journal of Personality and Social Psychology, 46, 26-43.

Eccles JS, Harold R (1991). Gender differences in sport involvement: Applying the Eccles' expectancy-value model. Journal of Applied Sport Psychology, 3, 7-35.

Felson RB, Reed M (1986). The effect of parents on the self-appraisals of children. Social Psychology Quarterly, 49, 302-308.

Feltz DL, Lirgg CD, Albrecht RR (1992). Psychological implications of competitive running in elite young distance runners: A longitudinal analysis. The Sport Psychologist, 6, 128-138.

Gould D, Eklund R, Petlichkoff L, Peterson K, Bump L (1991). Psychological predictors of state anxiety and performance in age-group wrestlers. Pediatric Exercise Science, 3, 198-208

Green BC, Chalip L (1997). Enduring involvement in youth soccer: The socialization of parent and child. Journal of Leisure Research, 29, 61-77.

Greendorfer SL (2002). Socialization processes and sport behavior. In T Horn (Ed). Advances in Sport Psychology ( $2^{\text {nd }}$ ed., 377-40 I). Champaign, IL: Human Kinetics.

Greendorfer SL, Lewko JH, Rosengren KS (2002). Family and gender-based influences in sport socialization of children and adolescents. In FL Smoll, RE Smith (Eds). Children and youth in sport: A biopsychosocial perspective (2 ${ }^{\text {nd }}$ ed., 153-186). Dubuque, IA: Kendall-Hunt Publishing.

Harter S (1978). Effectance motivation reconsidered: toward a developmental model. Human Development, 21, 34-64.

Harter S (1981). A model of intrinsic mastery motivation in children: Individual differences and developmental change. In WA Collins (Ed). Minnesota symposium on child psychology (Vol. 14, 215-255). Hillsdale, NJ: Erlbaum.

Hellstedt JC (1990). Early adolescent perceptions of parental pressure in the sport environment. Journal of Sport Behavior, 13, I35-144.

Horn TS, Amorose AJ (1998). Sources of competence information. In JL Duda (Ed). Advances in sport and exercise psychology measurement (49-63). Morgantown, WV: Fitness Information Technology.

Horn TS, Hasbrook CA (1986). Informational components influencing children's perceptions of their physical competence. In MR Weiss, D Gould (Eds). Sport for children and youths (8I-88). Champaign, IL: Human Kinetics.

Horn TS, Hasbrook CA (1987). Psychological characteristics and the criteria children use for self-evaluation. Journal of Sport and Exercise Psychology, 9, 208-221.

Horn TS, Weiss MR (199I). A developmental analysis of children's self-ability judgments in the physical domain. Pediatric Exercise Science, 3, 310-326.

Kimiecik JC, Horn TS (1998). Parental beliefs and children's moderate-to-vigorous physical activity. Research Quarterly for Exercise and Sport, 69 (2): I63-169

Kimiecik JC, Horn TS, Shurin CS (1996). Relationships among children's beliefs, perceptions of their parents' beliefs, and their moderate-to-vigorous physical activity. Research Quarterly for Exercise and Science, 67(3), 324-336.

Leff SS, Hoyle RH (1995). Young athletes' perceptions of parental support and pressure. Journal of Youth and Adolescence, 24, I87-203.

Lewthwaite R, Scanlan TK (1989). Predictors of competitive etrait anxiety in male youth sport participants. Medicine and Science in Sport and Exercise, 21, 221 -229.

McCullagh P, Matzkanin K, Shaw SD, Maldonado M (1993). Motivation for participation in physical activity: A comparison of parent-child perce3ived competence and participation motives. Pediatric Exercise Science, 5, 224-233. 
Mead GH (1934). Mind, self and society. Chicago: University of Chicago Press.

Nicholls JG (1984). Conceptions of ability and achievement motivation. In R Ames, C Ames (Eds). Research on motivation in education: Student motivation (Vol. I, 39-73). New York: Academic Press.

Nicholls JG (1989). The competitive ethos and democratic education. Cambridge, MA: Harvard University Press.

Ommundsen Y, Vaglum P (|99|). Soccer competition anxiety and enjoyment in young boy players: The influence of perceived competence and significant others' emotional involvement. International Journal of Sport Psychology, 22, 35-49.

Passer MW (1983). Fear of failure, fear of evaluation, perceived competence and selfesteem in competitive trait-anxious children. Journal of Sport Psychology, 5, I72-188.

Power TG, Woolger C (1994). Parenting practices and age-group swimming: A correlational study. Research Quarterly for Exercise and Sport, 65, 59-66.

Roberts GC (1975). Win-loss causal attributions of little league players. Mouvement, 7: 315-322.

Robinson DW, Howe BL (1989). Appraisal variable/affect relationships in youth sport: A test of Weiner's attributional model. Journal of Sport and Exercise Psychology, I1: $431-443$.

Scanlan TK (2002). Social evaluation and the competition process: A developmental perspective. In FL Smoll and RE Smith (Eds). Children and youth in sport: A biopsychosocial perspective (2nd ed.). Dubuque, IA: Kendall/Hunt.

Scanlan TK, Lewthwaite R ( 1984). Social psychological aspects of competition for male youth sport participants: I. Predictors of competitive stress. Journal of Sport Psychology, 6: 208-226.

Scanlan TK, Lewthwaite R ( 1986). Social psychological aspects of competition for male youth sport participants: IV. Predictors of enjoyment. Journal of Sport and Exercise Psychology, 8: 25-35.

Scanlan TK, Stein GL, Ravizza K (1989). An in-depth study of former elite figure skaters: II. Sources of enjoyment. Journal of Sport and Exercise Psychology, I I: 65-83.

VanYperen NW (1995). Interpersonal stress, performance level, and parental support: a longitudinal study among highly skilled young soccer players. The Sport Psychologist, 9: 225-24l.

Weiner B (1974). Achievement motivation and attribution theory. Morristown, NJ: General Learning Press.

Weiner B (1980). Human motivation. New York: Holt, Rinehart, and Winston.

Weiss MR, Wiese DM, Klint KA (1989). Head over heels with success: The relationship between self-efficacy and performance in competitive youth gymnastics. Journal of Sport and Exercise Psychology, I I: 444-45 I.

Welk G] (in press). The Youth Physical Activity Promotion Model: A conceptual bridge between theory and practice. Quest, 51: 5-23.

White SA (1996). Goal orientation and perceptions of the motivational climate initiated by parents. Pediatric Exercise Science, 8: 122- 129.

Wold B, Anderssen N (1992). Health promotion aspects of family and peer influences on sport participation. International Journal of Sport Psychology, 23: 343-359. 

Série

Investigação

Imprensa da Universidade de Coimbra

Coimbra University Press

2009

U

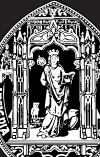

C 